\title{
DASHBOARD INFORMATION SYSTEM OF PEMINJAMAN UANG (PINANG) APPLICATION
}

\author{
Andiani ${ }^{1 *}$, M Farhan Zidni L. ${ }^{2}$ \\ Program Studi Teknik Informatika \\ Fakultas Teknik Universitas Pancasila Jakarta \\ http://teknik.univpancasila.ac.id \\ andiani@univpancasila.ac.id $\left.{ }^{1 *}\right), 4519217008 @$ univpancasila.ac.id ${ }^{2}$
}

(*) Corresponding Author

\begin{abstract}
Abstrak
Pinang adalah produk BRI Agro berbasis aplikasi digital yang berjalan dalam sistem operasi android, dimana dengan aplikasi tersebut nasabah dapat mengajukan permohonan pinjaman tanpa agunan secara digital, dimana saja dan kapan saja. Dalam perjalananya aplikasi Pinang tentu tidak selamanya berjalan mulus, selayaknya aplikasi pasti akan terus berkembang dan harus mampu mengahadapi tantangan dari berbagai sektor, begitupun dengan sistem yang berjalan pada aplikasi Pinang yang terus dikembangkan hingga saat ini, selaras dengan bertambahnya pengguna aplikasi pinang. Hal ini membuat tim operasional kesulitan dalam mengelola dan memonitoring data pengguna dengan jumlah pengguna yang semakin hari semakin bertambah jika tetap menggunakan cara konvensional. Tentunya perlu sebuah sistem yang dapat membantu proses pengelolaan data dari nasabah Pinang mulai dari penambahan kerjasama perusahaan dengan aplikasi Pinang sampai dengan maintance dan monitoring sistemnya secara digital. Maka di buatlah sistem informasi dashboard Pinang yang dapat membantu dalam operasional aplikasi Pinang yang mampu mengelola data, monitoring dan maintance apabila terdapat kendala pada proses peminjaman aplikasi Pinang. Dashboard Pinang dapat mempermudah dalam mengelola, memonitoring dan memberikan informasi terkait aplikasi Pinang. Dashboard pinang dibangun menggunakan model waterfall. Hasil dari penelitian ini adalah terciptanya sistem informasi dashboard aplikasi peminjaman uang Pinang.
\end{abstract}

Kata kunci: Pinang, Dashboard, Model Waterfall, Monitoring

\begin{abstract}
Pinang is a digital application-based BRI Agro product that runs on the Android operating system, where with this application customers can apply for loans without collateral digitally, anywhere and anytime. In its journey, the Pinang application certainly does not run smoothly, the application should continue to grow and must be able to face challenges from various sectors, as well as the system that runs on the Pinang application, which has continued to be developed to date, in line with the increasing number of users of the Pinang application. This makes it difficult for the operational team to manage and monitor user data with the number of users increasing day by day if they continue to use conventional methods. Of course, we need a system that can help the process of managing data from Pinang customers, starting from adding company cooperation with the Pinang application to maintaining and monitoring the system digitally. So a Pinang dashboard information system was created that can assist in the operation of the Pinang application that is able to manage data, monitor and maintain if there are problems in the Pinang application borrowing process. The Pinang dashboard can make it easier to manage, monitor and provide information related to the Pinang application. The areca dashboard is built using the waterfall model. The result of this research is the creation of a dashboard information system for the Pinang money lending application.
\end{abstract}

Keywords: Pinang, Dashboard, Waterfall Model, Monitoring

\section{INTRODUCTION}

Development in information technology and communication made an impact to the economy sector. Financial technology concept is adapted from technological developments combined with the financial sector in banking institutions, this is expected to facilitate the digital-based financial transaction process which is developed in Indonesia (Chrismastianto, 2017). There's a connecting between technology and financial. Nowdays there's a technology leads to financial innovation with 
touch of modern technology called Financial Technology.

Pinang is BRI Agro product based on digital application runs on android operation system, with this application customer can apply for a loan digitally (Wulananggraeni, 2020). In its journey, Pinang application certainly doesn't run smoothly, one of which is related to the system that runs on Pinang application which has continued to be developed until now.

Required system that can help to assist Pinang customer data processing, starting from team up with company until the maintance and monitoring application, so its need dashboard information system Pinang that can help the operational thing. There's a lack in facilities for operational team to do maintenance on the application, it was a hindrance for operational team in knowing the status of a registered customer. So, dashboard information system is made with API (Application Programming Interface) with waterfall model.

System design made with waterfall model is able to visualize customer data in graphical, with this display it can make easier way for operators to monitor the application (Sulistiawati \& Sulistiani, 2018) . Beside that using waterfall model provide facilities for operational team to maintenance Pinang application, like know customer status and build system that can manage, monitoring and give information related to Pinang Application.

Based on background, the purpose in this research is to facilitate the operational team in maintaining the Pinang application and building a system that can manage, monitor and provide information related to Pinang application.

\section{RESEARCH METHODS}

This study uses waterfall model, which is a model that describes a systematic and sequential approach to software development (Pressman, 2012). Besida that, waterfall model has clear and easy to understand stages, starting with requirements, namely specifications of user needs and then continuing through the stages of design, implementation, verification, and maintenance with support for the complete software produced.

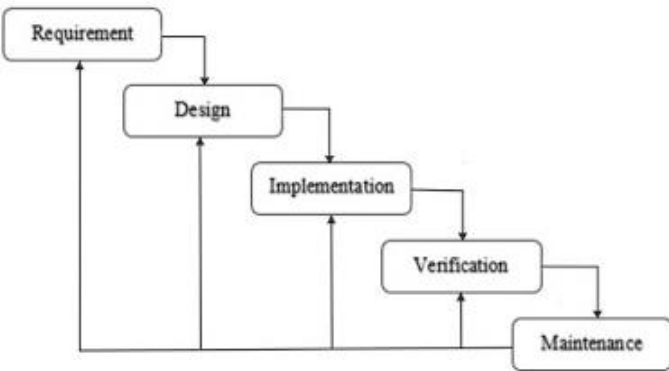

Figure 1. Waterfal Model

Waterfall model is a systematic and sequential information system development model (Pressman, 2012). Waterfall model has been widely used as an information system design, Research by (Sasmito, 2017) used waterfall model to design Tegal district industrial geographic information system. . Waterfall model has stages in the process like requirement, design, implementation, verification and maintenance. It make operational team easier to know information about industial profile and production data in every sub-district for every months and years in Tegal district.

\section{RESULT AND DISCUSSION}

\section{A. Requirement}

The scopes of the actor's needs in the Pinang dashboard application are:

1. Operator:

Operators are operational teams in charge of carrying out operational activities such as monitoring, checking data, searching for data and solving problems. Operators are only given read access and write permissions for the entire menu.

2. Supervisor:

Supervisor, namely the operational lead team who is responsible for operational activities. Supervisors are given read and write permissions for the entire menu.

3. Pimpinan:

Leaders, namely access rights given to leaders to be able to access the dashboard only to view data and reports. Leaders are given read access rights.

\section{B. Design}

\section{System Modeling}

The system is built using the Unified Modeling Language (UML) modeling language. UML is a system design model that has the advantage of making it easier for system developers to design the system to be built because of its object-oriented nature (Teguh, 2018). The UML modelling uses four 
types of diagrams, namely use case diagrams, activity diagrams, sequence diagrams, and class diagrams. Meanwhile, conceptual data modeling uses entity relationship diagram (Booch, 2005).

\section{a. Use Case Diagram}

One of the important diagrams used to illustrate the requirements of the system is a use case (UC) diagram. This diagram describes visually the context of the interaction between actors and the system. Each use case states a specification of the behavior (functionality) of the system being described that is needed by the actor to fulfill its objectives (Kurniawan, 2018).

Use Case Diagram system consists of three actors, namely; operators, supervisors, and leaders. All actors must be logged in, then each actor will be directed to the page that matches the roll.

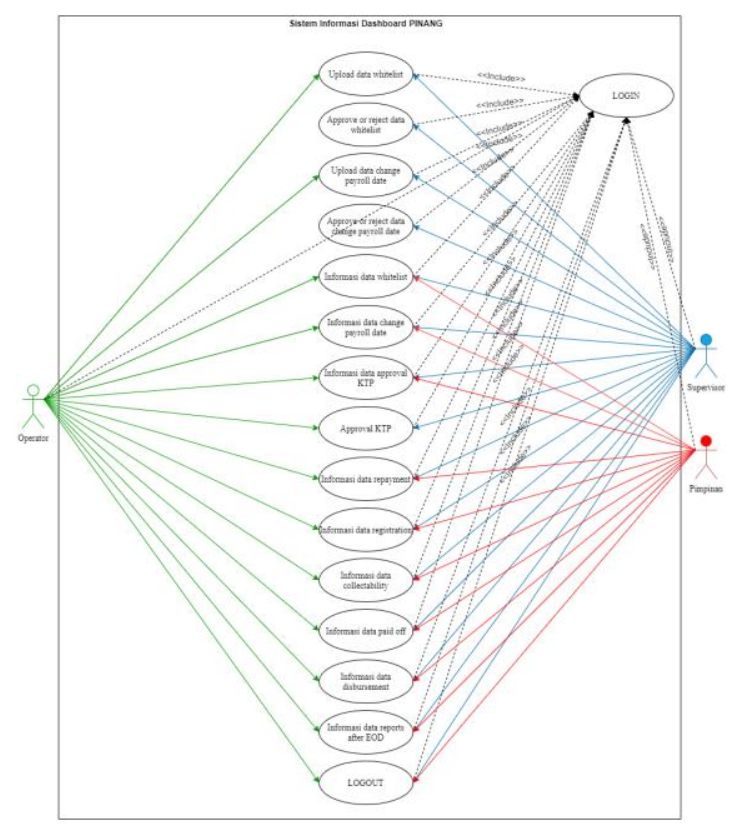

Figure 2. Use Case Diagram

Based on the use case diagram in Figure 2, operators can carry out activities in the system, including logging in, uploading whitelist data, updating data on change payroll dates, whitelist data information, information on change payroll date data, information on ID card approval data, information on repayment data, information on data registration, data collectability information, data disbursement information, paid off data information, after eod and logout data reports information. Meanwhile, the supersivor can perform activities on the system the same as the operator, except that the supervisor has the activity to approve or reject the data that has been uploaded by the operator and the leader can carry out activities on the system just to view the data and download the report.

\section{b. Activity Diagram}

Activity diagrams are an important component used in UML modeling. Activity Diagrams describe the workflow (work flow) of a system or business process or menu in the software (Aprianti \& Maliha, 2016).

\section{1) Activity Diagram Login}

Based on Figure 3, the login activity diagram illustrates the activities in the login process. The process begins by entering a username and password first. Then, the system validates the entered username and password. If the username and password entered is correct, the system will successfully enter the dashboard and display the main dashboard page. If it is wrong, an error info pop up will appear, you can re-enter the username and password. valid

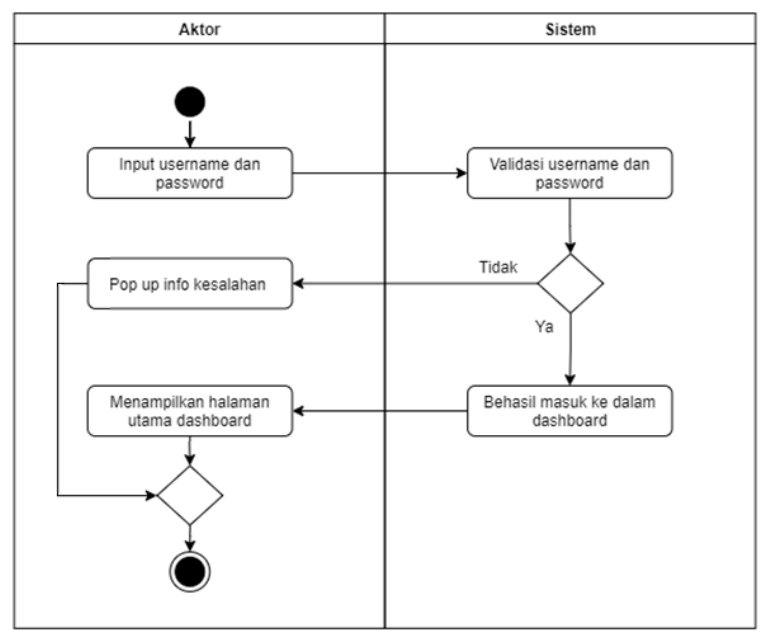

Figure 3. Login Activity Diagram

\section{2) Activity Diagram Upload Data Whitelist}

Based on Figure 4, the whitelist data upload activity diagram illustrates the activities in the whitelist data upload process. The process starts with the operator entering the whitelist menu and clicking upload file. Then, the system validates whether the user maker has uploaded it with a pending status. 


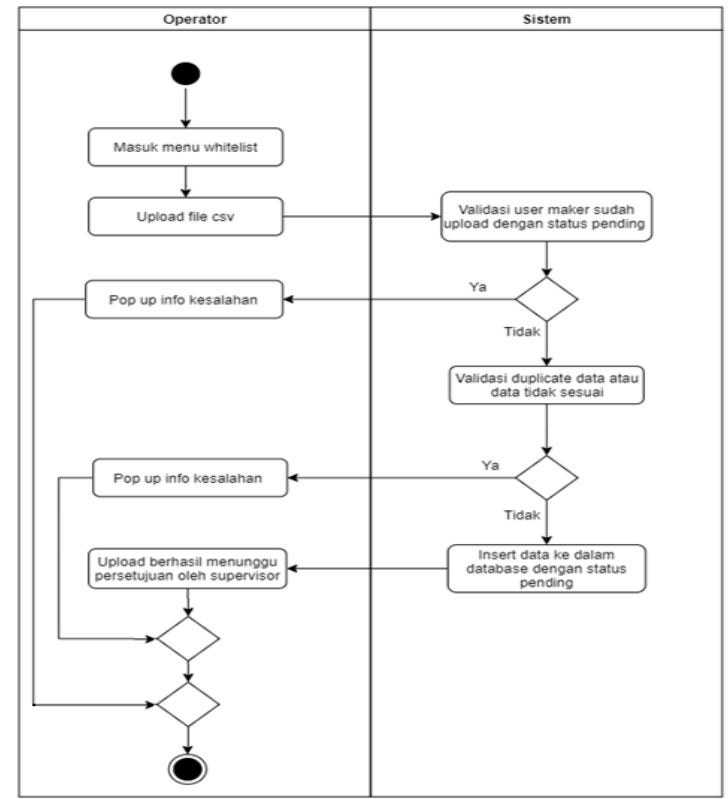

Figure 4. Whitelist Data Upload Activity Diagram

If so, an error pop up will appear and return to the file upload view. If not, the system will validate whether there is duplicate data, if there is duplicate data, it will display an error pop up if there is no duplicate data, then the upload is successful, the data is saved into the database and awaits the supervisor's approval.. This flow is also used for whitelist data input, it's just that the input is done per data.

3) Activity Diagram Approve or Reject Data Whitelist

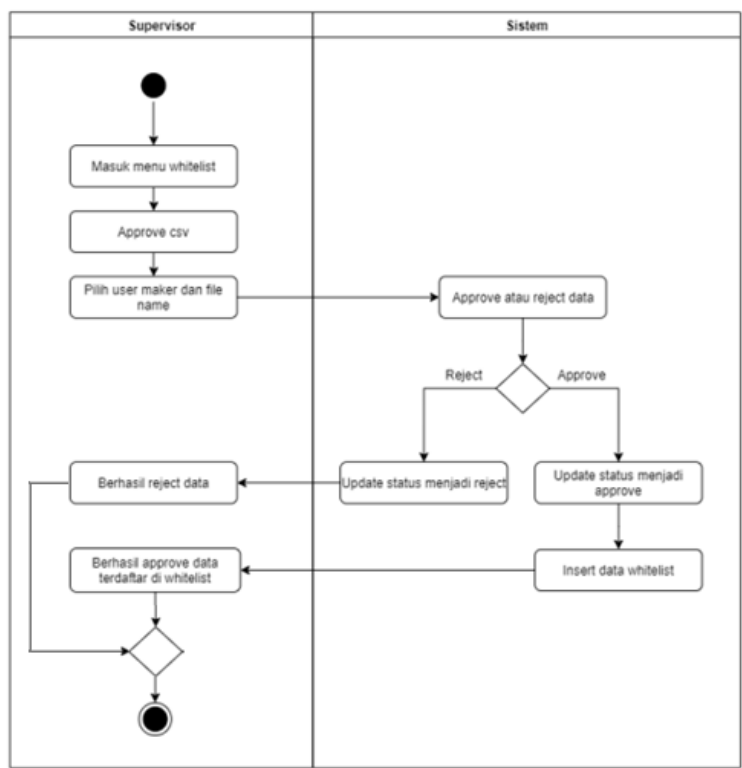

Figure 5. Activity Diagram Approve or Reject Data Whitelist

Based on Figure 5, the approve or reject data whitelist activity diagram illustrates the activities in the approve or reject whitelist data process. The process starts with the supervisor entering the whitelist menu and clicking approve $\mathrm{CSV}$. Then select the user maker and file name that will be approved or rejected. Then, the system validates if the reject status in the database will be updated to reject and not registered in the whitelist, if the approve status in the database will be updated to be approved so that the data is registered in the whitelist.

\section{c. Class Diagram}

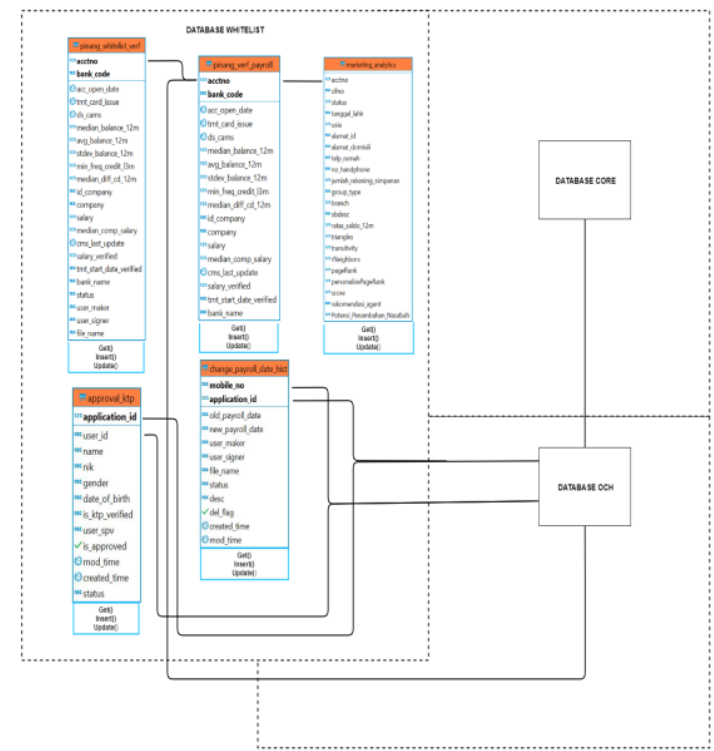

Figure 6. Class Diagram

Class Diagrams (Class Diagrams) are the relationships between classes and a detailed explanation of each class in the design model of a system, also showing the rules and responsibilities of entities that determine system behavior (Hendini, 2016).

Based on Figure 6, the class diagram is a visual of the program system structure on the types that are shaped. Class diagram is the flow of the database on a system. The class diagram in this application consists of three databases, namely the whitelist database which has five och database tables and core database.

\section{Database Modeling}

Entity Relationship Diagram (ERD) is a technique used to model the data needs of an 
organization, usually by a System Analyst in the requirements analysis stage of a system development project (Malcolm \& Loonam, 2010).

Based on Figure 7, ERD describes the relationship between entities. Each entity has

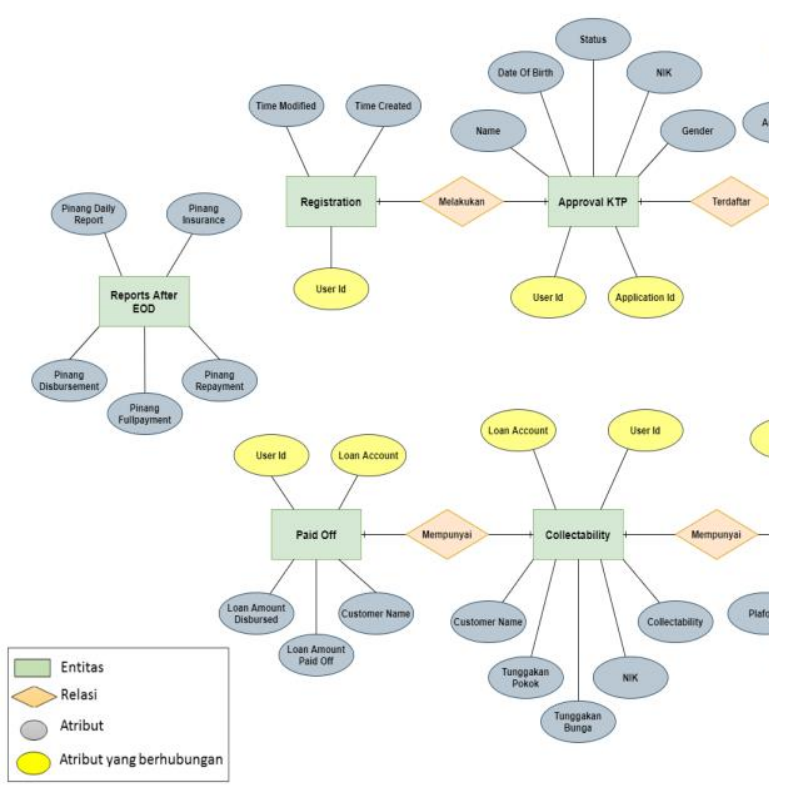

\section{System Implementation}

\section{Software Architecture}

Berdasarkan Figure 8 Perancangan Based on Figure 8, the design of the software architecture consists of input, process, output. Input consists of operators, supervisors, leaders, upload whitelist data, approve or reject data whitelist, update data change payroll date, approve or reject data change payroll date, KTP approval, data collectability information, data disbursement information, paid off data information and processing. eod.

The process consists of a login that is managed by a third party, namely keycloak, data management based on each menu which consists of a fire request, database, server, response api. The output consists of login info, dashboard display, whitelist data information, data change payroll date information, KTP approval data information, data repayment information, data registration information, data collectability information, data disbursement information, paid off data information and after-eod data reports information. attributes that are characteristics of the entity itself. ERD in this application has nine entities and fifty one attributes.

Figure 7. Entity Relationship Diagram (ERD)

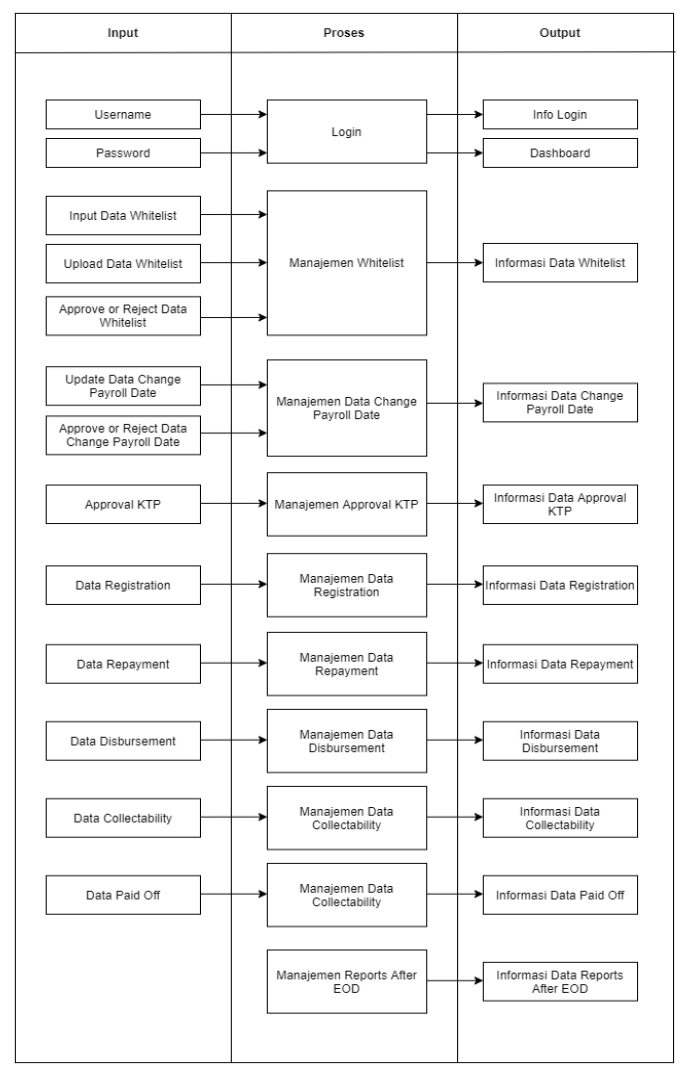

Figure 8. Software Architecture 


\section{Database Implementation}

Based on Figure 9 Database Implementation is obtained from the ERD design results which are then processed on the database using the open source DBeaver program as a database manager using the PostgresSQL database.

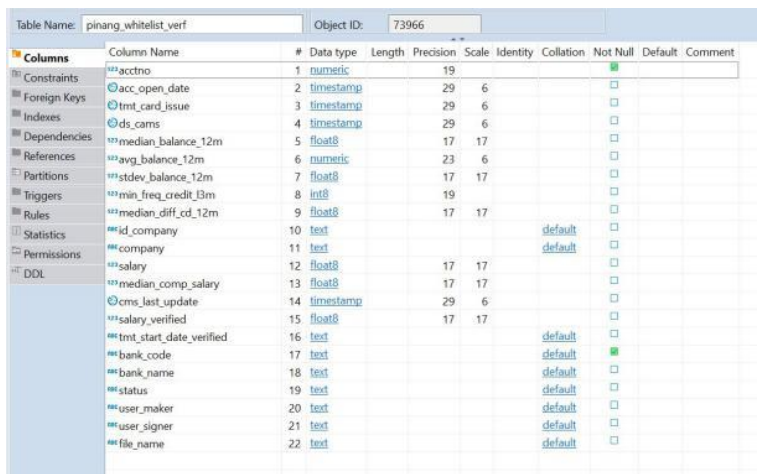

Figure 9. Database Implementation

\section{Implementation of Design Result}

Implementation of design results displays the results of a predetermined design, to send information to users through the system. The implementation of this application includes:
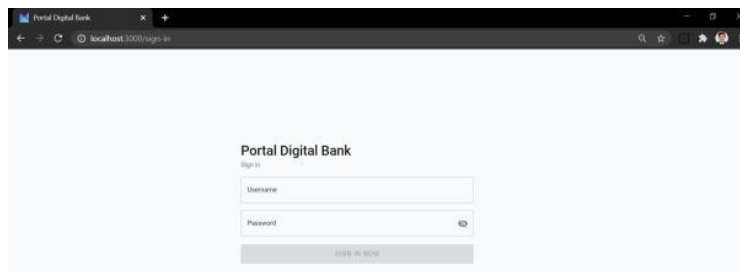

Figure 10. Login Page

In Figure 10, the login page is a page to enter the dashboard where you must enter a valid username and password, if it is not valid, an error pop up will appear. There are three types of roles they have, namely as operators, supervisors and leaders.

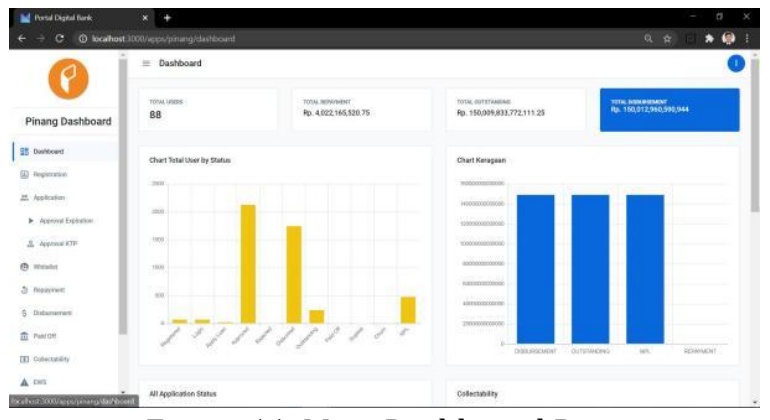

Figure 11. Main Dashboard Page
The main dashboard page displays several summaries of the total including total users, total repayments, total outstanding and total disbursements. It also displays information in graphical form for total user by status, performance, application status and collectability. As in Figure 11 and Figure 12.

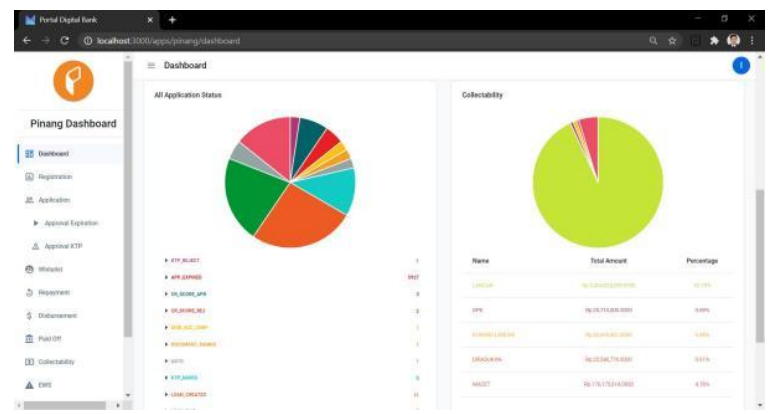

Figure 12. Main Dashboard Page

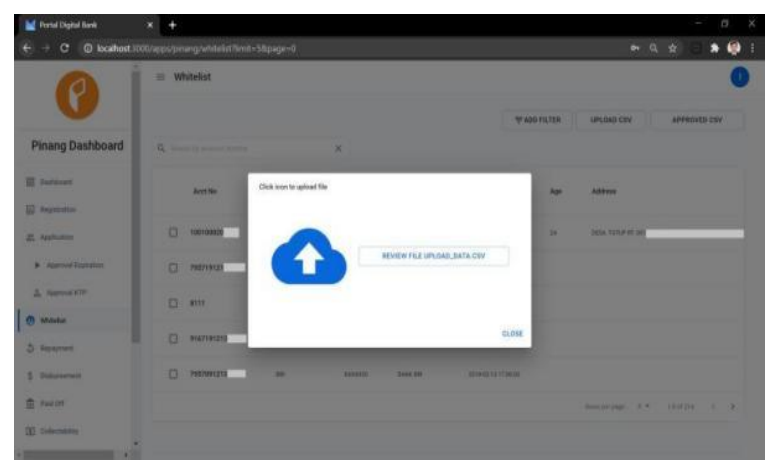

Figure 13. Upload Data Page

In Figure 13, the data upload page is used to input data in the form of a CSV file. This page appears when the csv upload button is clicked and asked to select a location to store the files to be uploaded.

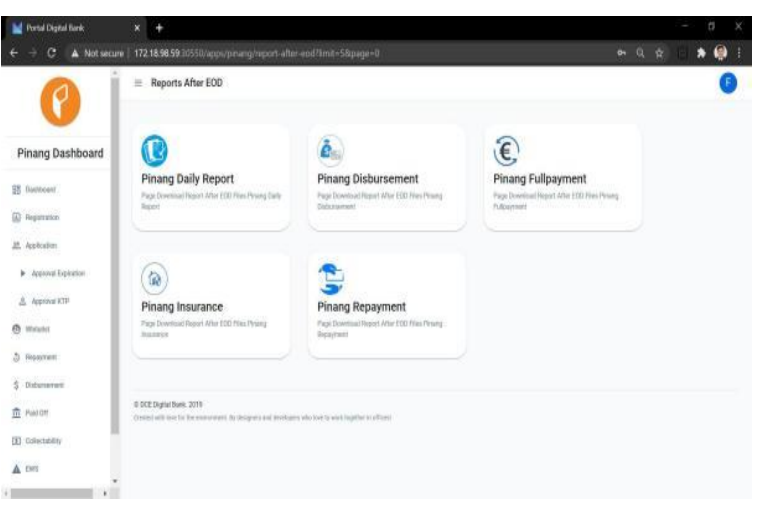

Figure 14. Report Page

In Figure 14, the reports page has five sub menus including areca daily reports, areca disbursement, areca nut fullpayment, areca insurance and areca repayment. 


\section{Verification}

At this stage the system that has been created will be integrated and UAT testing is carried out to test whether the system is functioning properly, to test the Pinang dashboard carried out by the Quality Assurance team or commonly called QA. Following are the test results on the Pinang dashboard application can be seen in Table 1 .

Table 1 Verification Testing

\begin{tabular}{|c|c|c|c|c|c|}
\hline $\begin{array}{l}\text { Test } \\
\text { Case }\end{array}$ & Scenario & $\begin{array}{l}\text { Expected } \\
\text { Result }\end{array}$ & $\begin{array}{l}\text { Complexi } \\
\text { ty }\end{array}$ & Result & $\begin{array}{l}\text { Statu } \\
\mathrm{s}\end{array}$ \\
\hline Sign In & $\begin{array}{l}\text { Input } \\
\text { Usernam } \\
\mathrm{e} \text { and } \\
\text { Passwor } \\
\mathrm{d} \text { that } \\
\text { has } \\
\text { registere } \\
\mathrm{d} \text { than } \\
\text { click } \\
\text { "Sign } \\
\text { Now" }\end{array}$ & $\begin{array}{l}\text { Usernam } \\
\text { e and } \\
\text { password } \\
\text { that has } \\
\text { been } \\
\text { input can } \\
\text { show } \\
\text { successfu } \\
\text { ly, and } \\
\text { enter into } \\
\text { dashboar } \\
\text { d }\end{array}$ & High & $\begin{array}{l}\text { Login } \\
\text { success } \\
\text { and can } \\
\text { go to } \\
\text { dashboa } \\
\text { rd page }\end{array}$ & $\begin{array}{l}\text { Passe } \\
\text { d }\end{array}$ \\
\hline $\begin{array}{l}\text { Whiteli } \\
\text { st }\end{array}$ & $\begin{array}{l}\text { In } \\
\text { search } \\
\text { by } \\
\text { account } \\
\text { number } \\
\text { from } \\
\text { Whitelist } \\
\text { menu } \\
\text { input } \\
\text { with } \\
\text { valid } \\
\text { data }\end{array}$ & $\begin{array}{l}\text { Show } \\
\text { account } \\
\text { number } \\
\text { data } \\
\text { containin } \\
\text { g input } \\
\text { data }\end{array}$ & Medium & $\begin{array}{l}\text { Show } \\
\text { account } \\
\text { number } \\
\text { data } \\
\text { containi } \\
\text { ng input } \\
\text { data }\end{array}$ & $\begin{array}{l}\text { Passe } \\
\text { d }\end{array}$ \\
\hline $\begin{array}{l}\text { Whiteli } \\
\text { st }\end{array}$ & $\begin{array}{l}\text { In search } \\
\text { by } \\
\text { account } \\
\text { number } \\
\text { from } \\
\text { Whitelist } \\
\text { Menu } \\
\text { input } \\
\text { orther } \\
\text { than } \\
\text { account } \\
\text { number }\end{array}$ & $\begin{array}{l}\text { Show } \\
\text { "There } \\
\text { are no } \\
\text { users" } \\
\text { Page }\end{array}$ & Medium & $\begin{array}{l}\text { Show } \\
\text { "There } \\
\text { are no } \\
\text { users" } \\
\text { Page }\end{array}$ & $\begin{array}{l}\text { Passe } \\
\text { d }\end{array}$ \\
\hline $\begin{array}{l}\text { Sign } \\
\text { Out }\end{array}$ & $\begin{array}{l}\text { Click } \\
\text { name } \\
\text { initial } \\
\text { Icon in } \\
\text { top right } \\
\text { than } \\
\text { click sign } \\
\text { out }\end{array}$ & $\begin{array}{l}\text { The } \\
\text { account } \\
\text { will be } \\
\text { sign out } \\
\text { and show } \\
\text { login } \\
\text { page }\end{array}$ & Medium & $\begin{array}{l}\text { The } \\
\text { account } \\
\text { will be } \\
\text { sign out } \\
\text { and } \\
\text { show } \\
\text { login } \\
\text { page }\end{array}$ & $\begin{array}{l}\text { Passe } \\
\text { d }\end{array}$ \\
\hline
\end{tabular}

\section{E. Maintenance}

At this stage the system that has been created will be integrated and UAT testing is carried out to test whether the system is functioning properly, to test the Pinang dashboard carried out by the Quality Assurance team or commonly called QA. Following are the test results on the Pinang dashboard application can be seen in Table 2 .
Table 2 Software Spesifications

\begin{tabular}{ll}
\hline Dev. Operating System & : Microsoft Windows 10 Profesional \\
\hline Server Operating System & : Linux UBUNTU 16.04 TLS \\
\hline IDE & : Visual Studio v.1.53.2 \\
\hline Code Navigation & : Jetbrains GoLand v.2020.1.2 \\
\hline DB management tool & : DBeaver v. 6 \\
\hline API Development & : Postman v. 8.0.6 \\
\hline Browser & : Google Chrome v. 89.0.4389.90 \\
\hline
\end{tabular}

\section{CONCLUCIONS AND SUGGESTIONS}

\section{Conclusions}

The Money Loan Application (Pinang) Dashboard Information System can facilitate the operational team in maintaining the Pinang application without the need to perform manual data queries in the database. The Money Loan Application (Pinang) Dashboard Information System provides customer status information from the Pinangbaik application in the form of numbers and graphics. The Cash Loan Application Dashboard Information System (Pinang) has been successfully built and features upload whitelist data and data change payroll date, approve or reject whitelist data and data change payroll date, KTP approval, whitelist data information, change payroll date, KTP approval, repayment, registration, collectability, disbursement, paid off and reports after EOD. Where these features can be used to manage, monitor and provide information related to the Pinang application

\section{Suggestions}

The system built in completing this final project is far from perfect. There are several suggestions that the author can submit in the next development, namely that all menus have a download feature so that they can be saved and this Pinang dashboard can continue to be developed following the development of the mobile Pinang application itself.

\section{REFERENCES}

Aprianti, W., \& Maliha, U. (2016). Sistem Informasi Pendataan Penduduk Kelurahan atau Desa Stusdi Kasus pada Kecamatan Bati-Bati Kabupaten Tanah Laut. Jurnal Sains Dan Informasi., Volume. 2,(2013), 21-28.

Booch, G. (2005). The Unified Modeling Language User Guide. Pearson Education India.

Chrismastianto, I. A. W. (2017). Analisis SWOT Implementasi Tekonologi Finansial terhadap 
Kualitas Layanan Perbankan di Indonesia. Jurnal Ekonomi Dan Bisnis, 20(1), 133-144. https://doi.org/10.24914/jeb.v20i1.641

Hendini, A. (2016). Pemodelan UML Sistem Informasi Monitoring Penjualan dan Stok Barang (Studi Kasus: Distro Zhezha Pontianak). Jurnal Khatulistiwa Informatika, IV(2), 107-116.

Kurniawan, T. A. (2018). Pemodelan Use Case (UML): Evaluasi Terhadap beberapa Kesalahan dalam Praktik. Jurnal Teknologi Informasi Dan Ilmu Komputer, 5(1), 77. https://doi.org/10.25126/jtiik.201851610

Malcolm, B., \& Loonam, J. (2010). Exploring the Use of Entity-Relationship Diagramming as a Technique to Support Grounded Theory Inquiry. Bradford: Emerald Group Publishing.

Pressman, R. S. (2012). Rekayasa Perangkat Lunak (Pendekatan Praktisi) Edisi 7: Buku 1. Yogyakarta: Andi Publisher.

Sasmito, G. W. (2017). Penerapan Metode Waterfall Pada Desain Sistem Informasi Geografis
Industri Kabupaten Tegal. Jurnal Informatika:Jurnal Pengembangan IT (JPIT), 2(1),

6-12. https://doi.org/http://dx.doi.org/10.30591/j pit.v2i1.435

Sulistiawati, S., \& Sulistiani, H. (2018). Perancangan Dashboard Interaktif Penjualan (Studi Kasus: PT Jaya Bakery). Jurnal Tekno Kompak, 12(1), 15-17. Retrieved from https://ejurnal.teknokrat.ac.id/index.php/te knokompak/article/view/61

Teguh, P. (2018). Unified Modeling Language (UML) Model Untuk Pengembangan Sistem Informasi Akademik Berbasis Web. Jurnal Informatika: Jurnal Pengembangan IT, 3(1), 126-129.

Wulananggraeni, M. J. (2020). Tinjuan Yuridis Pinjaman Tenang (PINANG) Sebagai Pinjaman Online Berbasis Aplikasi (Universitas Lampung). Universitas Lampung. Retrieved from

http://digilib.unila.ac.id/id/eprint/61588 